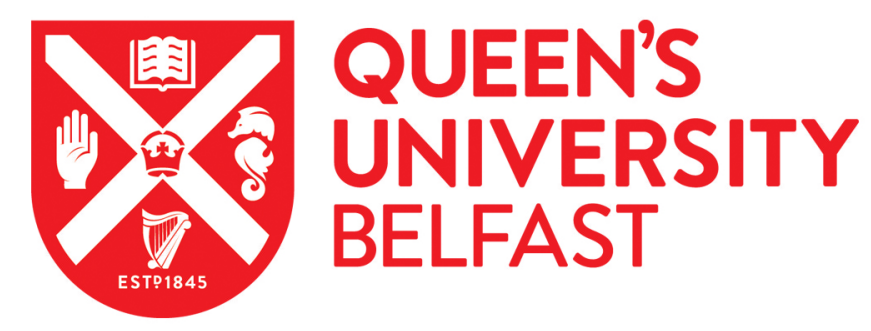

\title{
Chinese national policy initiative for the management of childhood myopia
}

Jan, C. L., \& Congdon, N. (2018). Chinese national policy initiative for the management of childhood myopia. The Lancet. Child \& adolescent health, 2(12), 845-846. https://doi.org/10.1016/S2352-4642(18)30318-3

\section{Published in:}

The Lancet. Child \& adolescent health

\section{Document Version:}

Peer reviewed version

\section{Queen's University Belfast - Research Portal:}

Link to publication record in Queen's University Belfast Research Portal

\section{Publisher rights}

Copyright 2018 Elsevier.

This manuscript is distributed under a Creative Commons Attribution-NonCommercial-NoDerivs License

(https://creativecommons.org/licenses/by-nc-nd/4.0/), which permits distribution and reproduction for non-commercial purposes, provided the author and source are cited

\section{General rights}

Copyright for the publications made accessible via the Queen's University Belfast Research Portal is retained by the author(s) and / or other copyright owners and it is a condition of accessing these publications that users recognise and abide by the legal requirements associated with these rights.

Take down policy

The Research Portal is Queen's institutional repository that provides access to Queen's research output. Every effort has been made to ensure that content in the Research Portal does not infringe any person's rights, or applicable UK laws. If you discover content in the Research Portal that you believe breaches copyright or violates any law, please contact openaccess@qub.ac.uk. 
Title: Chinese national policy initiative for the control of childhood myopia: Only the beginning for vision care reform

Authors: Catherine Jan, BOptom (Hon) ${ }^{1}$, Prof Nathan Congdon, MD ${ }^{2,3,4}$

\section{Affiliations:}

${ }^{1}$ School of Psychological and Cognitive Sciences, Peking University, Beijing, China. ${ }^{2}$ Queen's University Belfast, Belfast, United Kingdom. ${ }^{3}$ Orbis International, New York, NY, United States. ${ }^{4}$ State Key Laboratory of Ophthalmology, Zhongshan Ophthalmic Center, Sun Yat-sen University, Guangzhou, China

\section{Address for correspondence:}

MS Length: 836 words (Not including title page and references)

Version: 21 September 2018 
Vision impairment is responsible for half of disability among children in low and middleincome countries, ${ }^{1}$ with uncorrected refractive error (URE) the leading cause of vision impairment among children globally. ${ }^{2}$ Chinese children bear a unique burden: half of the world's children who are visually impaired by URE live in China, ${ }^{3}$ a number which is growing and expected to reach 100 million by $2020 .{ }^{4}$ The situation is particularly concerning in view of trial-proven educational benefits of spectacle ownership and use. ${ }^{5}$

Reasons for China's URE crisis are multifactorial: world-leading rates of myopia are driven by unrelenting education pressures, leading in turn to excessive near work burdens and insufficient time outdoors, both causally-related to myopia. ${ }^{6}$ Families' demand for glasses is blunted by lack of knowledge and a false belief that glasses weaken children's eyes. Service delivery is hamstrung by poorly-coordinated government efforts: the Ministry of Health focuses on blinding conditions such as cataract, and delegates school vision care to the Ministry of Education, which is ill-equipped to deliver effective strategies. Glasses are regulated by the Ministry of Commerce as commercial rather than medical products, and the certification and regulation of optometrists is overseen by the Ministry of Human Resources, neither of which is qualified technically for the role. Consequently, in rural areas half of children's glasses are inaccurate and two-thirds of providers have not completed secondary school. ${ }^{7}$ Finally, efforts to prevent myopia, which have focused since 1963 on un-proven traditional eye "exercises" (peri-orbital self-massage), have failed to curb spiking prevalence.

The Chinese government has recently taken strong action in the face of this crisis. For the last three years, the national "Love your Eyes Day" has focused on adolescent myopia, and recently Vice Premier Sun Chunlan has personally participated in myopia prevention and control activities at local Beijing primary schools. However, the most exciting recent development has been the announcement on 30 August 2018 of a comprehensive national children's myopia management plan, ${ }^{8}$ supported in an editorial by national leader Xi Jinping himself. Crucially, actions will be coordinated among eight separate central government bodies under the leadership of the Education Ministry. The multi-factorial nature of myopia has been recognized, and control activities outlined in five crucial spheres. These include government policies; school-based prevention, including lessening the homework burden and use of the proven intervention ${ }^{9}$ of increased outdoor time; screening and treatment of myopia in the health sector; parental encouragement of prevention efforts; and children's avoidance of risky behaviors such as excessive study and over-use of electronic devices.

Encouragingly, the plan outlines specific roles for each participating government body, encompassing those dealing with sport, news, radio and television. It also establishes concrete targets, including two hours of daily time outdoors for children, no written homework in the first two years of primary school, a daily maximum of 90 minutes even during the highly pressurized middle school years, and an annual national reduction of $0.5 \%$ in myopia prevalence between 2018 and 2023. Crucially, outcomes such as homework levels and myopia rates will now fall under the government's proven system of assessment and rewards, ${ }^{10}$ with bodies that fail to meet targets being held accountable.

The new comprehensive myopia control program represents a thoughtful and exciting first step towards achieving a comprehensive eye health system in China. However, important challenges remain. Fragmented decision-making is still an important problem. Despite healthcare reforms initiated in 2009, there is little coordination of care between levels of providers. Tertiary facilities are often over-burdened, while primary and secondary levels are weak, under-capacitated and under-utilised. In the area of children's refractive service, there is a compelling need to build primary and secondary service capacity, which the proposed plan does not fully address. 
Un-proven and biologically-implausible prevention strategies, such as traditional eye exercises, adoption of particular postures while reading and writing and avoidance of reading in bed and on vehicles play too large of a role in the current national plan, while proven strategies such as increased time outdoors deserve even greater emphasis. Burgeoning rates of health insurance coverage are a signal triumph of China's healthcare system over the last decade, but the current plan fails to leverage health insurance to reduce existing cost barriers to glasses ownership among China's rural and urban migrant children, only $20 \%$ of whom obtain glasses when they need them. ${ }^{5}$ Finally, many adults and children in China suffer from potentially pathologic levels of high myopia, visually-significant complications of which, including secondary cataract, glaucoma and retinal detachment, are un-addressed by glasses wear. The combination of prevention strategies and careful monitoring necessary to reduce the burden of severe vision impairment in the high myopia group, estimated to number 40-52 million in 2020 , is not well-described in the current plan.

Despite these limitations, the national plan for myopia control recently initiated by President $\mathrm{Xi}$ marks the first step in reforming the eye health care system in China. It represents a measured, strategic and powerful response to a major crisis of children's health in China, with important lessons for the rest of the world, which also faces climbing rates of myopia. 
Declaration of interests: The authors declare no competing interests.

\section{References}

1. Dimension of Disability in India, chapter 4.

http://mospi.nic.in/Mospi_New/upload/disablity_india_statistical_data_11mar2011/Ch apter\%204-Dimension_Disability.pdf. Table $4 . \overline{3}$ (b). (Website last viewed 18 September 2018).

2. Negrel AD, Ellwein LB; RESC Study Group. More research needed to assess the magnitude of refractive errors world-wide. Community Eye Health. 2000;13:11-2.

3. Resnikoff S, Pascolini D, Mariotti SP, Pokharel GP. Global magnitude of visual impairment caused by uncorrected refractive errors in 2004. Bull World Health Organ. 2008;86:63-70.

4. Sun HP, Li A, Xu Y, Pan CW. Secular trends of reduced visual acuity from 1985 to 2010 and disease burden projection for 2020 and 2030 among primary and secondary school students in China. JAMA Ophthalmol. 2015;133:262-8.

5. Ma X, Zhou Z, Yi H, Pang X, Shi Y, Chen Q, Meltzer ME, le Cessie S, He M, Rozelle $\mathrm{S}$, Liu Y, Congdon N. Effect of providing free glasses on children's educational outcomes in China. Cluster-randomized controlled trial. BMJ. 2014;349:g5740.

6. Morgan IG, Ohno-Matsui K, Saw SM. Myopia. Lancet. 2012;379:1739-48.

7. Zhou Z, Zeng J, Ma X, Pang X, Yi H, Chen Q, Meltzer M, He M, Rozelle S, Congdon $\mathrm{N}$. Accuracy of rural refractionists in western China. Invest Ophthalmol Vis Sci. 2014;55:154-61.

8. "A Chinese National Children's Myopia Treatment and Control Program." http://www.moe.edu.cn/jyb_xwfb/s271/201808/t20180831_346869.html?tdsourcetag =s_pctim_aiomsg. (Website in Chinese; last viewed 21 September 2018).

9. He M, Xiang F, Zeng Y, Mai J, Chen Q, Zhang J, et al. 2015. Effect of Time Spent Outdoors at School on the Development of Myopia Among Children in China: A Randomized Clinical Trial. JAMA 314:1142-8.

10. Li H, Zhou LA. Political turnover and economic performance: the incentive role of personnel control in China. J. Public Econ 2005;89:1743-62. 